\title{
PUBLIC SOCIAL PRIVATE PARTNERSHIP (PSPP) DALAM PENYEDIAAN INFRASTRUKTUR PUBLIK
}

\section{PUBLIC SOCIAL PRIVATE PARTNERSHIP (PSPP) IN THE PROVISION OF PUBLIC INFRASTRUCTURE}

\author{
Tomi Setiawan, dan Nosia Warsa \\ Departemen Administrasi Publik, FISIP Universitas Padjadjaran, Sumedang, Jawa \\ Barat \\ Pusat Studi Kebijakan Agraria Universitas Padjadjaran, Bandung, Jawa Barat \\ Email: tomi.setiawan@unpad.ac.id; nosiawarsa@gmail.com
}

Naskah diterima : 17 November 2017, Direvisi : 8 Desember 2017,

Disetujui : 11 Desember 2017

\begin{abstract}
Purpose of this research is to explain phenomenon of public infrastructure provision through Public Social Private Partnership (PSPP) mechanism. PSPP basically offers an opportunity for community organizations to act between the government and the private sector in the provision of public services. Sumedang is a regency that has started the mechanism to build and develop market infrastructure through PSPP mechanism. It is intended to allow the market development activities quickly and to get legitimation from all parties. This research uses qualitative method. Data are collected through in-depth interviews and secondary literature. This research is important to gain theoretical support as well as practice at the level of the actors. Result of the research indicates that PSPP offers multi-actor involvement in the process of providing public infrastructure, however this engagement results a more difficult proces in fulfilling their interests.
\end{abstract}

Keywords: public social private partnership, public infrastucture.

\begin{abstract}
Abstrak
Tujuan dari penelitian ini adalah untuk menjelaskan fenomena penyediaan infrastruktur publik yang dilakukan melalui mekanisme Public Social Private Partnership (PSPP). PSPP secara prinsiptual menawarkan kesempatan kepada organisasi masyarakat untuk bertindak antara pemerintah dan swasta dalam penyediaan layanan publik. Kabupaten Sumedang merupakan kabupaten yang telah memulai sebuah mekanisme untuk merencanakan pengembangan dan pembangunan infrastruktur pasar melalui mekanisme PSPP dengan tujuan agar kegiatan pengembangan pasar tersebut dapat terlaksana dalam waktu yang cepat dan mendapatkan legitimasi dari semua pihak. Metode penelitian yang digunakan adalah kualitatif dengan mengutamakan wawancara mendalam dan studi literatur sebagai teknik pengumpulan datanya. Kajian ini menjadi penting terutama untuk
\end{abstract}


mendapatkan dukungan secara teoritis, maupun secara praktis pada tingkat aktor-aktor yang terlibat. Sebagai kesimpulan, PSPP menawarkan keterlibatan multi-aktor dalam proses penyediaan infrastruktur publik, namun di sisi lain keterlibatan ini mempengaruhi proses yang lebih sulit untuk memenuhi kepentingan di antara para aktor yang terlibat.

Kata kunci: Kemitraan antara Pemerintah, swasta, dan organisasi sosial, infrastruktur publik.

\section{A. PENDAHULUAN}

Paradigma administrasi publik selalu berkembang sesuai dengan tuntutan zaman. Salah satu paradigma yang diterapkan oleh beberapa pemerintah dan daerah saat ini adalah paradigma New Public Governance (NPG) yang berkembang sejak awal tahun 2000an. Paradigma ini menjelaskan bahwa perkembangan penyelenggaraan pemerintahan menjadi lebih terbuka dalam proses pembuatan dan pelaksanaan kebijakan. Penyelenggaraan sistem pemerintahan yang semakin terbuka tentunya memberikan kesempatan luas bagi pihak swasta dan masyarakat untuk terlibat dalam penyelenggaraan pemerintahan tersebut. Keterlibatan multi-aktor dalam paradigma ini terjadi karena keterbatasan pemerintah dalam sumber daya atau sarana prasarana untuk menyediakan layanan publik yang berkualitas. Hubungan antar aktor dalam penyelenggaraan pemerintahan tentu akan mempermudah pemerintah untuk mewujudkan layanan publik yang lebih baik. Merujuk pendapatnya Osborne (2010), salah satu cara untuk melibatkan multi-aktor tersebut adalah dengan kemitraan. Dalam penelitian ini secara lebih spesifik disebut Public Social Private Partnership (PSPP), yaitu suatu kerjasama yang yang melibatkan antara pemerintah, pihak swasta, dan organisasi sosial masyarakat, khususnya dalam penyediaan infrastruktur publik.

PSPP melibatkan minimal tiga mitra, alasannya adalah karena terdapat tiga peran penting yaitu pembiayaan infrastruktur untuk penerapan melalui pengembangan pelayanan publik, menganalisis kebutuhan, ide, koordinasi dari perencanaan melalui pengaturan dan operasi, dan permintaan layanan dari masyarakat sebagai jaminan arus kas dengan menyetujui untuk menggunakan layanan(Leonhardt, dkk., 2007). Lebih jauh dijelaskannya bahwa PSPP menawarkan kesempatan kepada organisasi masyarakat untuk bertindak antara pemerintah dan swasta dalam penyediaan layanan publik. Seluruh aktor terlibat tentu akan menanggung resiko dan keuntungan berdasarkan kesepakatan dalam perjanjian. Lahirnya PSPP ini dilatarbelakangi oleh hal perencanaan, pembiayaan, pengembangan, dan kualitas layanan yang bersifat jangka menengah maupun jangka panjang. Model kerjasama ini memiliki kesempatan untuk mengantisipasi kebutuhan masa depan dan mengembangkan layanan yang inovatif.

Penelitian PSPP di Indonesia saat ini masih jarang ditemukan, dan penelitian ini merupakan salah satu pionir dalam penelitian terkait dengan pelibatan tiga sektor dalam perkembangan paradigma terbaru administrasi publik. Penelitian sejenis yang pernah ada sering kali hanya melibatkan dua sektor saja yakni pemerintah dan swasta, seperti pada hasil penelitian Setiawan dan Sukma (2012) dijelaskan bahwa kemitraan antara pemerintah daerah dan pihak swasta tanpa adanya legitimasi dari organisasi sosial masyarakat berpengaruh besar terhadap keberhasilan tujuan kemitraan. Oleh karena itu model kemitraan yang dapat digunakan untuk pengembangan pasar seharusnya tidak hanya melibatkan pemerintah daerah dan pihak swasta saja, tetapi juga melibatkan dan memberdayakan para pedagang yang ada di pasar tersebut. Penelitian lain yang mengkaji keterlibatan pemerintah dan swasta dapat dilihat juga pada Susantono dan Berawi (2012) yang membahas perkembangan kebijakan skema kemitraan pemerintah dan swasta di Indonesia dalam upaya menghasilkan value for money pada proyek pembangunan infrastruktur transportasi. Menurut penelitian tersebut pembangunan infrastruktur transportasi merupakan salah satu poin vital dalam 
peningkatan pertumbuhan ekonomi, dan sebagai salah satu alternatif untuk dapat membiayai pembangunan proyek infrastruktur transportasi di Indonesia.

PSPP dilakukan dalam rangka mempercepat pembangunan infrastruktur sehingga pelayanan kepada masyarakat lebih berkualitas. Salah satu pemerintah daerah yang telah melaksanakan PSPP adalah Pemerintah Daerah Kabupaten Sumedang. PSPP di Kabupaten Sumedang dilaksanakan dalam sektor perpasaran. Menurut data dalam Profil Kabupaten Sumedang Tahun 2015, pasar tradisional di Kabupaten Sumedang saat ini mulai mengalami degradasi fungsi. Hasil observasi langsung di lapangan menunjukkan kondisi gedung pasar yang sudah tidak layak, tidak beraturan dan kumuh. Selain itu menurut hasil wawancara awal dengan salah satu staf Bappeda Kabupaten Sumedang memberikan gambaran lain bahwa, semakin banyaknya pasar modern juga menjadi penyebab degradasi fungsi pasar tradisional. Masyarakat lebih memilih berbelanja ke pasar modern karena kenyamanan dan kebersihan. Saat ini perbandingan jumlah pasar modern dan pasar tradisional di Kabupaten Sumedang cukup signifikan. Pasar modern yang ada di Sumedang berjumlah sekitar 67 unit meliputi minimarket dan supermarket, sedangkan jumlah pasar tradisional dibawah binaan pemerintah daerah Kabupaten Sumedang hanya 11 unit saja.

Berdasarkan kondisi tersebut, menurut penjelasan dalam Buku Profil Daerah Kabupaten Sumedang Tahun 2015, pemerintah daerah Kabupaten Sumedang kemudian berinisiatif untuk merencanakan pengembangan dan pembangunan pasar tradisional yang ada di Kabupaten Sumedang. Pengembangan pasar ini dilakukan mengingat persaingan pasar yang semakin meningkatkan di Indonesia. Studi kelayakan yang dilakukan oleh Badan Perencanaan Pembangunan Daerah (Bappeda) Kabupaten Sumedang menghasilkan keputusan untuk melaksanakan pengembangan pasar tradisional agar mampu bersaing dengan pasar modern.

Dalam pengembangan pasar ini, pemerintah daerah bekerjasama dengan pihak swasta beserta masyarakat untuk mengelola dan memberdayakan pasar tradisional. Kerjasama ini didasarkan pada Peraturan Pemerintah Nomor 50 Tahun 2007 tentang Tata Cara Pelaksanaan Kerjasama Daerah. Dalam PP tersebut dijelaskan bahwa kerjasama daerah merupakan kesepakatan dalam hal ini antara bupati dengan pihak ketiga yang dibuat secara tertulis serta menimbulkan hak dan kewajiban. Permasalahannya kemudian adalah kemitraan dalam pengembangan pasar ini mengalami kemandekan. Setelah berjalan hampir tiga tahun pelaksanaan kerjasama antara pemerintah daerah Kabupaten Sumedang, PT. Bangun Jaya Allia, dan Ikwapa dalam pengembangan pasar PPKS belum berjalan optimal. Hal ini terlihat dari belum dilaksanakan pembangunan fisik pasar PPKS menjadi pasar semi modern Sumedang Kota. Berdasarkan hasil wawancara, Kepala Kantor Pemasaran PT. Bangun Jaya Allia menjelaskan bahwa selama dua tahun bekerjasama, pihak PT. Bangun Jaya Allia belum dapat melaksanakan pembangunan gedung pasar akibat keterlambatan pemindahan pedagang ke TPS yang dilakukan oleh pemerintah.

Selanjutnya, dalam pengembangan pasar ini pemerintah daerah Kabupaten Sumedang tentunya juga harus melibatkan para pedagang pasar. Seperti yang terdapat dalam Peraturan Daerah Nomor 3 Tahun 2014 tentang Pengelolaan dan Pemberdayaan Pasar Tradisional serta Penataan Pusat Perbelanjaan dan Toko Modern pasal 8, dijelaskan bahwa pemerintah daerah bertugas untuk melakukan koordinasi antar lembaga pemerintah, masyarakat, pelaku pasar, dan instansi terkait agar terdapat keterpaduan dalam pengelolaan dan pemberdayaan pasar. Selain itu, dalam peraturan daerah tersebut pasal 31 juga dijelaskan bahwa pedagang berhak untuk berpartisipasi dalam proses pengambilan keputusan, penyelenggaraan, dan pengawasan di bidang pengelolaan pasar. Akan tetapi masalah lain ditemukan pada saat penjajakan awal, dengan diperoleh informasi bahwa belum didapatkan persetujuan dari pedagang sebagai pihak yang terkena dampak dari kegiatan ini. Bahkan dari data yang bersumber dari surat kabar lokal dan yang diberitakan pada pikiran rakyat online, 
pedagang yang masih memiliki hak guna bangunan merasa dirugikan dengan pelaksanaan pengembangan pasar ini.

Berdasarkan latar belakang penelitian tersebut, maka peneliti mengidentifikasi masalah sebagai berikut: Bagaimana Public Social Private Partnership dalam penyediaan infrastruktur publik, khususnya dalam pengembangan pasar PPKS di Kabupaten Sumedang? Oleh karenanya tulisan ini bertujuan untuk menjelaskan Public Social Private Partnership antara Pemerintah Daerah Kabupaten Sumedang, PT. Bangun Jaya Allia, dan Ikwapa PPKS dalam Pengembangan Pasar PPKS Kabupaten Sumedang.

\section{B. METODE PENELITIAN}

Metode penelitian yang digunakan dalam penelitian ini adalah metode kualitatif. Menurut Creswell (2010) penelitian kualitatif adalah jenis penelitian dimana peneliti sangat tergantung terhadap informasi dari objek/partisipan pada: ruang lingkup yang luas, pertanyaan yang bersifat umum, pengumpulan data yang sebagian besar terdiri atas kata-kata/teks dari partisipan, menjelaskan dan melakukan analisa terhadap kata-kata dan melakukan penelitian secara subyektif. Pada penelitian ini peneliti mengamati apa yang terjadi di lapangan, mencatat segala hal yang terjadi dengan teliti, melakukan analisis terhadap dokumen-dokumen yang ditemukan di lapangan dan kemudian dituangkan ke dalam laporan penelitian secara detail.

Teknik pengumpulan data dilakukan dengan beberapa cara yaitu, observasi non-partisipatif, wawancara, sStudi pustaka dan dokumentasi. Observasi non-partisipatif dilakukan di pasar PPKS Kabupaten Sumedang dengan melihat bagaimana proses pengembangan pasar yang dilakukan oleh pemerintah daerah Kabupaten Sumedang, PT. Bangun Jaya Allia sebagai pengembang serta respon dari pedagang pasar yang terkena dampak penataan pasar tersebut. Kemudian wawancara dilakukan terhadap (1) Kepala Seksi Pengembangan Bidang Pasar Daerah Dinas Koperasi, UMKM, Perindustrian, dan Perdagangan Kabupaten Sumedang; (2) Ketua IKWAPA PPKS Kabupaten Sumedang; (3) Kepala Kantor Pemasaran PT. Bangun Jaya Allia; serta beberapa pedagang pasar PPKS. Selanjutnya, dengan metode studi pustaka, peneliti melakukan pengumpulan data yang diperoleh dengan cara membaca, mempelajari literatur-literatur yang relevan dengan masalah penelitian ini serta arsip-arsip yang berhubungan dengan Public Social Private Partnership dalam pengembangan pasar PPKS Kabupaten Sumedang.

Dalam melakukan analisis data, penulis menggunakan teknik analisis data kualitatif yang dikemukakan oleh Miles and Huberman. Analisis data tersebut dilakukan dengan tiga langkah menurut Miles and Huberman (1994) yaitu data reduction (reduksi data), data display (penyajian data), dan conclusion drawing/verification (penarikan kesimpulan dan verifikasi. Selanjutnya, peneliti menggunakan teknik triangulasi untuk melihat keabsahan data. Bentuk triangulasi yang digunakan untuk menguji keabsahan data yang didapatkan di lapangan dalam penelitian ini adalah triangulasi sumber. Triangulasi sumber berarti membandingkan dan mengecek balik kepercayaan suatu informasi yang diperoleh melalui waktu dan alat yang berbeda dalam penelitian kualitatif (Moleong, 2007)

\section{KERANGKA TEORI}

Administrasi publik sebagai disiplin ilmu bertujuan untuk memecahkan masalah publik melalui perbaikan-perbaikan terutama di bidang pelayanan publik dan organisasi manajemen melalui kebijakan publik. Administrasi publik saat ini dimaksudkan untuk lebih memahami hubungan pemerintah dengan publik serta meningkatkan responsibilitas kebijakan terhadap berbagai kebutuhan publik dan juga mengembangkan praktik-praktik 'co-production' agar pelaksanaan kegiatan administrasi publik 
dapat efektif, efisien, ekonomis dan berkeadilan. Bovaird, dan Löffler menjelaskan 'co-production' terkait perubahan konteks kebijakan publik ini, bahwa :

“It is important to distinguish 'co-production' from public consultation and public participation. Here, coproduction is considered as the most intensive form of citizen engagement where the focus is on joint action, whereas public participation involves mainly communication processes with joint decision-making and public consultation involves mainly listening. The definition above includes these activities as part of 'co-production' as long as they entail the public making important contributions, which are being used by the public sector.” (Bovaird, dan Löffler, 2009)

Di sisi lain Vigoda-Gadot (2002) mengidentifikasikan tiga ruang lingkup dalam studi administrasi publik yaitu political science and policy analysis, sociology and cultural studies, and organization management and the business yang juga terdiri dari the Organizational Behavior (OB) and Human Resource (HR) subdivisions. Dalam hal ini administrasi publik tidak hanya terkait dengan ilmu politik dan analisis kebijakan, tetapi juga pemahaman mengenai dinamika kelompok dan struktur informal serta pendekatan kewirausahaan untuk menyediakan layanan publik.

Administrasi publik merupakan kegiatan melayani masyarakat. Pemerintah melaksanakan kebijakan untuk memenuhi kebutuhan masyarakat tersebut. Hal ini juga berkaitan dengan aspek manajemen, untuk melaksanakan kegiatan administrasi publik. Mullin (1996) menjelaskan bahwa, "Management does include administration, but also involves organization to achieve objectives with maximum efficiency, as well as genuine responsibility for results”. Definisi tersebut bermakna bahwa tidak hanya manajemen yang termasuk dalam administrasi tetapi juga melibatkan organisasi untuk mencapai tujuan dengan efisien. Lebih lanjut Minogue (1998) menambahkan beberapa hal terkait proses administrasi publik selain efisiensi, bahwa, "modern public administration is not just about efficiency; it also involves ideas of democratic participation, accountability and empowerment". Ini berarti dalam administrasi publik modern, pelaksanaan kegiatan untuk melayani publik tidak hanya untuk menciptakan efisiensi tetapi juga menyangkut peningkatan pastisipasi, akuntabilitas dan pemberdayaan. Seiring dengan adanya tuntutan dari masyarakat yang semakin berkembang membuat pemerintah harus mampu menampung aspirasi masyarakat dan juga melibatkan aktor lain yang ingin berpartisipasi agar tersedianya layanan publik yang berkualitas.

Seiring dengan perkembangan paradigma administrasi publik, segala bentuk kerjasama untuk menciptakan layanan publik telah mulai dilaksanakan. Sejak tahun 1990-an, paradigma administrasi publik telah berkembang menjadi New Public Governance. Paradigma ini adalah tentang pentingnya interaksi aktor pemerintah dan non-pemerintah dipandu dan diarahkan dalam pengambilan keputusan secara kolektif. Sebagaimana dijelaskan Vasudha Chhotray and Gerry Stoker bahwa ini adalah tentang aturan pengambilan keputusan kolektif dalam pengaturan di mana ada sejumlah aktor atau organisasi dan di mana tidak ada sistem kontrol resmi dapat mendikte hubungan antara aktor dan organisasi. (Chhotray dan Stoker, 2009)

Governance merupakan proses mengendalikan kegiatan organisasi dan hubungan dengan para pemangku kepentingan internal maupun eksternal. Menjelajahi konteks, dinamika, dan pada akhirnya wacana paradigma New Public Governance telah menyoroti hubungan dan interaksi antara skala spasial yang berbeda dan berbagai aktor dan lembaga. Sebagaimana dijelakan Osborne (2010) bahwa New Public Governance merupakan sebuah paradigma baru dalam administrasi publik yang menyeimbangkan peran, tanggung jawab, akuntabilitas dan kemampuan: berbagai tingkat pemerintahan lokal, nasional, regional dan global serta aktor yang berbeda atau sektor dalam masyarakat, public, private and civil society organizations dan warga negara. 
Kemitraan merupakan suatu hubungan antar sektor yang mencakup perorangan, kelompok, atau organisasi yang setuju untuk bekerjasama memenuhi kewajiban atau mengerjakan tugas tertentu, menanggung resiko, dan manfaat bersama, meninjau kembali hubungan secara teratur, dan merevisi persetujuan sesuai kebutuhan. Seperti yang dijelaskan Stratton dalam Osborne (2010) bahwa kemitraan merupakan kerjasama antara pihak swasta, organisasi sosial, dan pemerintah di mana risiko, sumber daya dan keterampilan dibagi dalam pengembangan yang menguntungkan pihak serta masyarakat

Kemitraan sering kali dilaksanakan untuk meningkatkan efektivitas pemerintahan. Dalam Glasbergen, et al dijelaskan bahwa:

"Kemitraan digunakan untuk menggambarkan berbagai jenis hubungan, terkadang mengacu pada hubungan antara pemerintah saja, tetapi juga hubungan antara aktor dari sektor-sektor lain dari masyarakat, seperti pelaku pasar atau masyarakat sipil”. (Glasbergen, et al, 2007)

Kemitraan tiga sektor pada umumnya didorong oleh pencampuran antara motif self-interest dengan keinginan untuk mewujudkan kebaikan bersama (Selsky dan Parker dalam Dwiyanto, 2008). Kemitraan ini dilatarbelakangi oleh dorongan untuk menjawab berbagai masalah sosial yang semakin kompleks dan tidak memungkinkan untuk diselesaikan oleh masing-masing institusi ataupun oleh kerjasama antara pemerintah dengan salah satu sektor lainnya. Dalam menanggapi kebutuhan masyarakat yang semakin meningkat maka pemerintah melibatkan berbagai aktor yaitu pihak swasta, dan organisasi sosial masyarakat untuk bekerjasama dalam penyediaan layanan publik. Urgensi dari kerjasama ini adalah untuk mengatasi keterbatasan pemerintah baik dari sumber daya dan sarana prasana dalam menyediakan kebutuhan publik. Salah satu bentuk kerjasama yaitu Public Social Private Partnership (kemitraan antara pemerintah, organisasi sosial, dan swasta).

Menurut Porter dan Kramer (2006) salah satu solusi potensial untuk konflik kepentingan dan salah urus tata kelola pemerintahan adalah melalui penerapan PSPP, yang telah muncul dalam beberapa tahun terakhir sebagai sarana untuk lebih menyelaraskan kepentingan pemangku kepentingan, yang tidak berfokus pada maksimalisasi keuntungan, namun untuk menciptakan nilai sosial yang lebih luas. Lebih jauh mereka menjelaskan fenomena yang relatif baru dari PSPP ini sangat sesuai apabila diterapkan pada sektor infrastruktur, kesehatan, dan pertanian berskala besar dalam memenuhi kebutuhan publik mendasar di mana sektor publik sering mengalami kekurangan sumber daya untuk solusi komprehensif.

Public Social Private Partnership (PSPP) adalah bentuk kemitraan antara pemerintah, pihak swasta, dan masyarakat sosial dalam perencanaan, pembiayaan, dan pelaksanaan layanan publik untuk menciptakan perlindungan sosial dan untuk memperbaiki kehidupan orang-orang yang termajinalkan. Sebagaiman dijelaskan Fandel bahwa:

"Public Social Private Partnership (PSPP) dipahami bahwa lembaga-lembaga pemerintah, perusahaan swasta, yayasan dan individu swasta bersama-sama melaksanakan proyek yang meningkatkan kesejahteraan dan berorientasi sosial”. (Fandel et al, 2012)

Public Social Private Partnership merupakan salah satu penerapan administrasi publik dalam paradigma governance. PSPP ini merupakan kerjasama antara pemerintah, swasta dan organisasi sosial dimana pemerintah sebagai leading sector, pihak swasta sebagai penyedia modal investasi (pembiayaan), dan organisasi sosial sebagai penerima layanan publik. Public Social Private Partnership melibatkan organisasi sosial untuk pengembangan dan pelaksanaan tujuan sosial. Dua karakteristik utama dari PSPP yaitu : 
a. Tujuan sosial: Melaksanakan kegiatan untuk perlindungan, dukungan dan peningkatan kesempatan bagi orang-orang yang kurang beruntung atau kelompok orang yang kurang beruntung.

b. Implementasi dalam kemitraan: Konsep kemitraan antara public, pihak swasta, dan organisasi sosial ekonomi.

(Leonhardt et al, 2007)

Lebih jauh Leonhardt et al,(2007) menjelaskan PSPP merupakan prasyarat untuk memastikan bahwa kemitraan multi-aktor memiliki tujuan sosial, menjamin dan melaksanakan tujuan umum, agenda dan tugas dalam arti manfaat masyarakat, kesejahteraan, dan sebagainya. Kemudian juga mampu mematuhi dan mendukung agenda dan tujuan kerjasama dalam jangka menengah dan panjang, serta rencana dan sesuai menerapkan kondisi dan sumber daya yang diperlukan (misalnya pembiayaan) untuk hasil yang berkelanjutan .

Berbagai keuntungan dari penerapan mekanisme PSPP dapat dilihat dalam penjelasan Komisi Uni Eropa (2004) bahwa, pertama bagi negara, dengan menangani fungsi negara dalam bentuk kemitraan, mitra negara memperoleh opsi untuk tindakan melalui bentuk kemitraan langsung dengan swasta dalam pembiayaan, atau dengan melibatkan mitra tambahan dari perusahaan swasta dan organisasi sosial dalam melakukan hal-hal yang dengan bertanggung jawab pada negara. Semua aspek ini memungkinkan negara untuk melakukan tugasnya dengan cara yang lebih menyeluruh, profesional dan berkelanjutan dengan membawa tambahan keuangan, keahlian, dan sumber daya praktis. Kedua bagi swasta, PSPP membuka kemungkinan untuk jenis kegiatan bisnis baru melalui kerja sama dengan negara dan organisasi sosial. PSPP menawarkan kesempatan kepada organisasi sosial untuk bertindak dalam peran ideal mereka dan menjadi perantara antara negara dan sektor swasta, membantu memastikan bahwa kontribusi masing-masing mitra terhadap proyek sesuai dengan kapasitas masing-masing sektor. Hal ini juga dapat mengurangi risiko bagi semua aktor. Aktor organisasi sosial memperoleh keuntungan dari PSPP dalam hal perencanaan, pengembangan dan kualitas terhadap proyek jangka menengah dan panjang. Dan ketiga, bagi organisasi sosial PSPP dapat berarti jaminan layanan yang mereka butuhkan, dan bahwa sesuai dengan konsep negara kesejahteraan, telah membantu memenuhi harapan-harapannya mengantisipasi kebutuhan masa depan dan mengembangkan solusi dan layanan inovatif.

Inti dari PSPP adalah kemitraan yang menurut Budäus (2006) harus memiliki karakteristik: (1) terdapat tujuan dan manfaat dari organisasi (aktor) yang berpartisipasi dan kompatibel satu sama lain; (2) setiap aktor harus bisa menciptakan tercipta sinergi; dan (3) identitas pada setiap organisasi organisasi tetap utuh atau tidak terkooptasi. Oleh karena itu, dalam PSPP, ketiga karakteristik tersebut harus dilaksanakan. Sehingga terdapat aktor yang memastikan pembiayaan, kemudian ada aktor bertanggung jawab atas keseluruhan proyek dan dengan demikian mengarahkan koordinasi proyek dari perencanaan melalui pengaturan dan realisasi produk atau layanan sosial (kepemimpinan proyek) dan setidaknya salah satu aktor yang memastikan aliran dana ke dalam proyek dengan membeli produk atau layanan. Ketiga karakteristik ini, idealnya diambil oleh tiga aktor dan / atau organisasi yang memiliki kompetensi dan tanggung jawab yang relevan. Dan sinergi juga bisa dibuat antara dua perusahaan atau organisasi.

Dalam penelitian ini, peneliti menggunakan prinsip-prinsip untuk menilai keberhasilan Public Social Private Partnership yang diungkapkan oleh Leonhardt et al, (2007) yang terdiri dari transparansi dan komitmen, pengawasan pelaksanaan kemitraan, proses negosiasi, dan kesetaraan peran dalam kemitraan. Melalui empat prinsip tersebut, akan mampu menjelaskan pelaksanaan Public Social Private Partnership antara pemerintah, pihak swasta, dan organisasi masyarakat. 


\section{HASIL DAN PEMBAHASAN}

\section{Gambaran Umum Penelitian}

Pada bagian ini, peneliti akan menjabarkan serta menganalisis data yang telah diperoleh selama penelitian mengenai Public Social Private Partnership (PSPP) antara Pemerintah Daerah Kabupaten Sumedang, PT. Bangun Jaya Allia (PT. BJA), dan IKWAPA (Ikatan Kerukunan Warga Pasar) PPKS dalam pengembangan Pasar Pusat Perbelanjaan Kota Sandang (PPKS) di Kabupaten Sumedang. Secara umum gambar berikut ini dapat meringkas penjelasan pada sub-bagian ini.

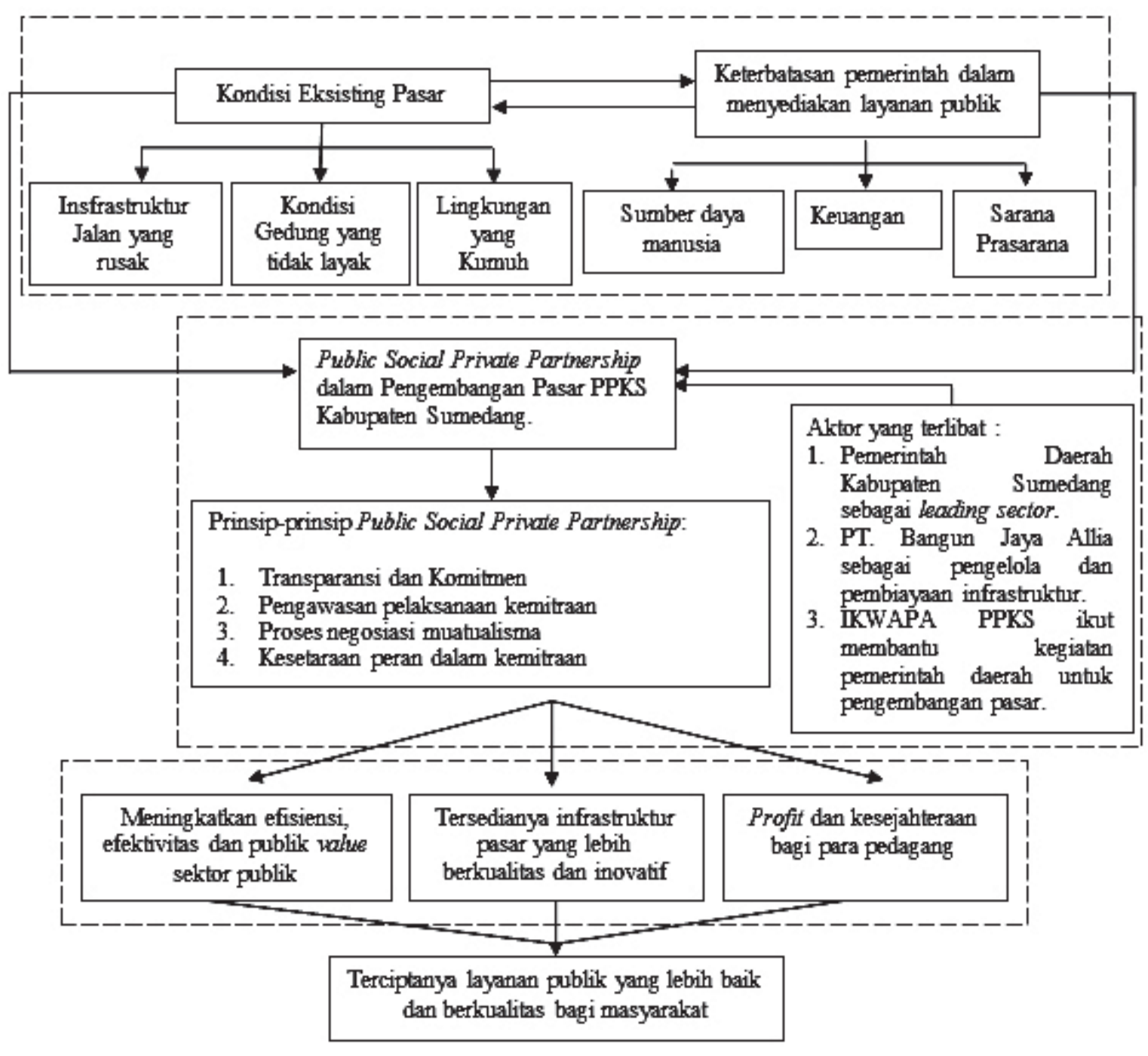

Gambar 1. Skema Penelitian

Menurut data pada Buku Profil Kabupaten Sumedang 2015, Kabupaten Sumedang merupakan salah satu Kabupaten di Provinsi Jawa Barat yang memiliki luas wilayah 155.871,98 Ha sesuai dengan Peraturan Daerah Kabupaten Sumedang Nomor 2 Tahun 2012 yang terdiri dari 26 kecamatan terbagi ke dalam 276 desa dan 7 kelurahan. Menurut data dari Dinas Kependudukan dan Catatan Sipil tahun 2013 mencatat bahwa jumlah penduduk Kabupaten Sumedang sebanyak 1.307.648 jiwa. 
Kondisi perekonomian di Kabupaten Sumedang pada tahun 2015 menunjukkan adanya penurunan yaitu sebesar 4,60 persen bila dibandingkan dengan tahun sebelumnya sebesar 4,69 persen. Maka arah pembangunan perekonomian Kabupaten Sumedang dapat diprioritaskan melalui beberapa sektor yaitu sektor pertanian, sektor pertambangan dan penggalian, sektor industri pengolahan, sektor listrik, gas, dan air bersih, sektor perdagangan, hotel, dan restoran, sektor keuangan, persewaan dan jasa perusahaan, dan sektor jasa pariwisata (BPS Kabupaten Sumedang, 2015).

Sektor perdagangan, hotel, dan restoran merupakan sektor kedua setelah pertanian yang berperan dalam pembentukan PDRB Kabupaten Sumedang. Perkembangan sektor perdagangan di Kabupaten Sumedang saat ini perlu ditingkatkan. Penguatan sektor perdagangan, hotel, dan restoran diarahkan dalam upaya penataan pasar modern dan revitalisasi pasar tradisional. Kebijakan yang ditujukan untuk penguatan penataan pasar salah satunya yaitu perlindungan dan pengembangan pasar tradisional. Oleh karena itu, dengan adanya penguatan sektor-sektor pembangunan perekonomian maka diharapkan kinerja perekonomian Kabupaten Sumedang pada tahun-tahun mendatang dapat terlaksana dengan baik.

Kegiatan yang dapat dilakukan agar perekonomian mengalami pertumbuhan yaitu meningkatkan kuantitas dan kualitas infrastuktur. Infrastruktur yang merupakan aset fisik untuk menyediakan jasa dan digunakan dalam produksi dan konsumsi akhir salah satunya yaitu pasar. Pasar memegang peranan penting dalam menggerakkan perekonomian masyarakat. Keberadaan pasar sangat besar manfaatnya bagi sebagian besar masyarakat karena merupakan tempat pemenuhan kebutuhan seharihari.

Berdasarkan Peraturan Daerah Kabupaten Sumedang Nomor 3 Tahun 2014, pasar yaitu area tempat jual beli barang dengan jumlah penjual lebih dari satu pihak baik yang disebut sebagai pusat perbelanjaan, pasar tradisional, pertokoan, mall, plaza, pusat perdagangan maupun sebutan lainnya. Saat ini pemerintah daerah Kabupaten Sumedang sedang melakukan kegiatan pengembangan pasar tradisional untuk menciptakan infrastuktur pasar yang berkualitas.

Pasar tradisional berdasarkan Perda tersebut dijelaskan sebagai area tempat jual beli barang dengan jumlah penjual lebih dari satu yang dibangun dan dikelola oleh pemerintah daerah dengan tempat usaha berupa kios, los, dan tenda yang dimiliki atau dikelola oleh pedagang kecil, menengah, swadaya masyarakat atau koperasi dengan usaha kecil, modal kecil, dan dengan proses jual beli barang dagangan melalui tawar menawar. Kegiatan pengembangan pasar tersebut meliputi pengelolaan dan pemberdayaan pasar tradisional. Pengelolaan pasar tradisional adalah pengelolaan seluruh potensi yang ada di wilayah pasar tradisional dan penataan pasar tradisional yang meliputi perencanaan, pelaksanaan dan pengendalian pasar tradisional. Sedangkan pemberdayaan pasar trandisional adalah segala upaya pemerintah daerah dalam memberdayakan seluruh potensi pasar serta melindungi keberadaan pasar tradisional agar mampu berkembang lebih baik untuk dapat bersaing dengan pusat perbelanjaan dan toko modern. 
Tabel 1. Pasar Tradisional Di Kabupaten Sumedang

\begin{tabular}{|c|c|c|c|c|c|c|c|c|c|c|}
\hline \multirow{2}{*}{ No. } & \multirow{2}{*}{ Nama Pasar } & \multirow{2}{*}{$\begin{array}{l}\text { Luas } \\
\text { Lahan }\end{array}$} & \multicolumn{2}{|c|}{$\begin{array}{l}\text { Keadaan } \\
\text { Fisik }\end{array}$} & \multicolumn{3}{|c|}{ Jumlah Pedagang } & \multicolumn{2}{|c|}{ Jumlah } & \multirow{2}{*}{ Ket. } \\
\hline & & & Kios & Los & Kios & Los & PKL & $\begin{array}{l}\text { Kios } \\
\text { Tutup }\end{array}$ & $\begin{array}{l}\text { Los } \\
\text { Tutup }\end{array}$ & \\
\hline 1. & Pasar Inpres & $8.650 \mathrm{~m}^{2}$ & 353 & 312 & 348 & 291 & 450 & 5 & 21 & \\
\hline 2. & $\begin{array}{ll}\text { Pasar } & \text { PPK } \\
\text { Sandang } & \\
\end{array}$ & $11.812 \mathrm{~m}^{2}$ & 423 & - & 211 & - & 436 & 169 & - & \\
\hline 3. & Pasar Tanjungsari & $14.000 \mathrm{~m}^{2}$ & 610 & - & 469 & - & 215 & 141 & - & \\
\hline 4. & $\begin{array}{l}\text { Pasar } \\
\text { Parakanmuncang }\end{array}$ & $3.446 \mathrm{~m}^{2}$ & 233 & - & 189 & - & 150 & 42 & - & \\
\hline 5. & Pasar Wado & $6.483 \mathrm{~m}^{2}$ & 232 & - & 195 & - & 30 & 37 & - & \\
\hline 6. & Pasar Dammaraja & $4.200 \mathrm{~m}^{2}$ & 197 & - & 88 & - & 20 & 84 & - & \\
\hline 7. & Pasar Conggeang & $2.000 \mathrm{~m}^{2}$ & 96 & 45 & 77 & 38 & 36 & 19 & 7 & \\
\hline 8. & Pasar Buahdua & $1 . .400 \mathrm{~m}^{2}$ & 38 & 58 & 22 & - & 5 & 16 & - & \\
\hline 9. & Pasar Ujungjaya & $1.400 \mathrm{~m}^{2}$ & 64 & - & 37 & - & 10 & 27 & - & \\
\hline 10. & Pasar Cikeramas & $840 \mathrm{~m}^{2}$ & - & 41 & - & - & - & - & - & \\
\hline 11. & Pasar Tolengas & - & - & - & - & - & - & - & - & \\
\hline
\end{tabular}

Sumber: Kabupaten Sumedang dalam Angka Tahun 2015

Berdasarkan Tabel 1 tersebut dapat terlihat bahwa Pasar PPKS (Pusat Perbelanjaan Kota Sandang) Sumedang merupakan salah satu pasar yang cukup berpotensi untuk dikembangkan karena pasar ini terletak di salah satu kawasan strategis Kabupaten Sumedang dari sudut kepentingan pertumbuhan ekonomi yaitu kawasan perkotaan Kabupaten Sumedang. Pasar yang dibangun pada

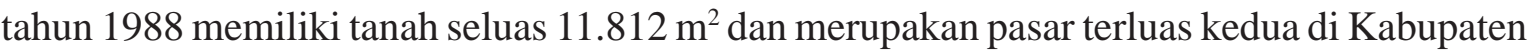
Sumedang. Jenis barang yang didagangkan berupa sandang, elektronik, perhiasan, dan sejenisnya dengan jumlah 423 kios dan 436 PKL.

Pasar PPKS ini terletak di pusat kota Kabupaten Sumedang dan keberadaannya sangat strategis sebagai penyedia kebutuhan masyarakat. Hampir seluruh masyarakat dari wilayah Kabupaten Sumedang mengunjungi pasar ini karena dianggap sebagai pusat perdagangan. Pasar ini dilalui trayek angkutan umum dalam kota yaitu jalur trayek Sumedang-Paseh, Sumedang-Kadipaten, SumedangTanjung Sari, Sumedang-Cileunyi, Sumedang-Situraja, Sumedang-Wado, Sumedang-Rancakalong, serta trayek antar kabupaten yaitu Bandung-Majalengka-Cirebon.

Pada saat penelitian ini berlangsung, kondisi gedung di pasar PPKS sudah tidak layak, hasil observasi menunjukkan bahwa dinding-dinding pasar yang sudah keropos. Selain itu tiang-tiang penyangga gedung sudah terlihat rapuh. Atap gedung pasar yang terbuka juga menjadi penyebab pasar menjadi becek jika curah hujan tinggi. Selain di dalam gedung pasar, kondisi infrastruktur jalan di sekitar pasar juga tidak memadai. infrastruktur jalan di sekitar pasar banyak yang berlubang. Jika musim hujan telah tiba, lubang ini akan menimbulkan genangan air dan tentu akan menyebabkan pasar menjadi kumuh dan mengganggu kenyaman konsumen saat berbelanja. Selain itu, jumlah PKL di sisi luar gedung juga menjamur. Banyaknya PKL membuat kondisi pasar semakin sempit dan tidak beraturan.

Melihat kondisi pasar, pemerintah daerah Kabupaten Sumedang membuat kebijakan untuk melakukan pengembangan pasar agar mampu bersaing dengan pasar modern. Latar belakang pengembangan pasar yaitu terkait dengan misi Kabupaten Sumedang untuk mewujudkan ketahanan pangan dan perekonomian daerah yang tangguh dan bertumpu pada potensi sumber daya daerah yang berkelanjutan untuk meningkatkan kesejahteraan masyarakat. Kaitan dengan peningkatan infrastruktur perekonomian daerah tidak terlepas dari unsur-unsur penunjang aktivitas perekonomian 
seperti barang, modal, pasar, sarana prasarana, transportasi, dan infrastruktur lainnya. Maka dari itu, diperlukan pembenahan infrastruktur pasar tradisional di daerah karena akan berdampak pada peningkatan kesejahteraan masyarakat.

Dalam melakukan pembangunan suatu daerah, pemerintah seringkali dihadapkan pada keterbatasan dalam menciptakan infrastruktur yang berkualitas bagi masyarakat. Keterbatasan tersebut terkait dengan keterbatasan sumber daya manusia, keuangan, serta sarana dan prasarana. Keterbatasan tersebut harus diatasi oleh pemerintah melalui kerjasama atau kemitraan dengan pihak swasta dan organisasi sosial. Kemitraan antar aktor ini memiliki beberapa manfaat diantaranya:

1. Menciptakan efektif dan efisiensi dalam penyelenggaraan pemerintahan.

2. Penyediaan infrastruktur yang lebih cepat.

3. Tersedianya infrastruktur dan sarana prasarana yang lebih inovatif.

4. Terciptanya infrastruktur yang berkualitas bagi masyarakat. (Glasbergen, et al, 2007)

Oleh karena itu, kemitraan antara pemerintah, organisasi sosial, dan pihak swasta atau Public Social Private Partnership merupakan kegiatan yang penting untuk mengatasi keterbatasan pemerintah dalam menyediakan infrastruktur.

Kemitraan ini terjadi karena adanya rencana pembangunan oleh Pemerintah Daerah Kabupaten Sumedang terkait dengan pengembangan pasar untuk memperbaiki infrastruktur dan fasilitas pasar agar memberikan kenyamanan bagi warga pasar. Pemerintah tersebut telah melakukan studi kelayakan pasar Sumedang yang menghasilkan rekomendasi bahwa pasar Sumedang Kota memerlukan adanya penataan termasuk pengaturan sistem penempatan kios dan penanganan PKL.

Pengembangan pasar PPKS yang merupakan salah satu kegiatan pembangunan daerah dengan melibatkan pihak ketiga dan organisasi sosial sebagai salah satu upaya untuk meningkatkan partisipasi swasta dan masyarakat. Pemerintah sebagai leading sector telah memilih PT. BJA untuk menjadi investor pengembangan pasar PPKS. Kerjasama yang dilakukan antar Pemerintah Daerah Kabupaten Sumedang dan PT. BJA dilaksanakan berdasarkan Peraturan Pemerintah Nomor 50 Tahun 2007 tentang Tata Cara Pelaksanaan Kerjasama Daerah. Dalam peraturan tersebut dijelaskan bahwa pemerintah daerah dapat bekerjasama dengan pihak ketiga dalam penelitian ini yaitu perusahaan swasta berbadan hukum PT. BJA. Selain melibatkan pihak ketiga, pemerintah juga melibatkan IKWAPA yang merupakan organisasi sosial yang menaungi seluruh aspirasi pedagang pasar. Saat ini, Pemerintah Daerah Kabupaten Sumedang, PT. Bangun Jaya Allia, dan IKWAPA telah bermitra untuk pengembangan pasar PPKS. Hubungan yang baik antara pemerintah, pihak swasta, dan IKWAPA tentunya akan menjadi jalan keluar untuk terlaksananya pengembangan pasar dan tersedianya infrastruktur pasar yang berkualitas.

Kemitraan dalam pengembangan pasar PPKS Kabupaten Sumedang antara pemerintah dan swasta ditetapkan dalam Surat Perjanjian Nomor 511/PKS.50-Huk/2013. Perjanjian kerjasama untuk jangka waktu 25 tahun tersebut ditandatangani pada tanggal 30 Januari 2013. Selain itu, organisasi sosial dalam hal ini IKWAPA Pasar PPKS juga dilibatkan dalam pengembangan pasar ini karena IKWAPA menjembatani hubungan antara sesama warga pasar dengan pemerintah dan memiliki peran serta dalam membantu tugas pengelolaan pasar dalam rangka menciptakan kelestarian lingkungan pasar.

Maksud diadakannya kemitraan dalam pengembangan pasar adalah untuk menciptakan pasar yang representatif, tertata secara baik, bersih, tertib, aman dan nyaman yang didukung dengan sarana prasarana penunjang yang baik dan memadai di Kabupaten Sumedang yang pada akhirnya 
dapat meningkatkan pendapatan masyarakat dan warga pasar Sumedang Kota. Berdasarkan maksud tersebut, maka kemitraan dalam pengembangan pasar ini memiliki tujuan untuk:

1. Membangun dan mengelola pasar Sumedang Kota secara profesional agar dapat terpelihara,

2. Sebagai upaya peningkatan pelayanan kebutuhan masyarakat,

3. Menciptakan kondisi fisik pasar tradisional yang representatif,

4. Untuk menjaga dan mendorong eksistensi pasar tradisional di Kabupaten Sumedang,

5. Meningkatkan Pendapatan Asli Daerah (PAD),

6. Menciptakan lapangan usaha dan lapangan kerja bagi masyarakat, dan

7. Menciptakan kenyamanan bagi pedagang dan konsumen pasar Sumedang Kota.

\section{Analisis Mekanisme PSPP dalam Penyediaan Infrastruktur Pasar PPKS}

\section{Transparansi dan Komitmen Para Pihak.}

Pada bagian ini akan dijelaskan sesuai dengan metode penelitian yang digunakan yakni kualitatif dengan melihat kondisi empirik dikaitkan dengan kerangka teoritik khusunya prinsip-prinsip PSPP dari Leonhardt et al, (2007). Dalam prinsip ini dijelaskan bahwa terjaminnya akses dan kebebasan bagi setiap pihak untuk memperoleh informasi terkait penyelenggaraan pemerintahan baik informasi tentang kebijakan, proses pembuatan, dan pelaksanaan serta tujuan yang hendak dicapai. Keberhasilan kemitraan dalam pengembangan pasar ini ditentukan dengan bagaimana setiap aktor yang terlibat dapat mengetahui maksud dan tujuan dari pengembangan pasar tersebut. Selain itu juga harus mengetahui manfaat dan risiko dari kemitraan ini. Informasi terkait kebijakan atau kegiatan pemerintah juga harus tersampaikan kepada seluruh pihak yang terlibat agar tidak terjadi miskomunikasi antar pihak.

Pasar merupakan tempat pemenuhan kebutuhan sehari-hari dan sebagai penggerak perekonomian masyarakat. Pemerintah Daerah Kabupaten Sumedang melakukan pengembangan pasar melihat kondisi pasar yang sudah tidak beraturan dan kondisi gedung yang mulai rapuh. Berdasarkan hasil wawancara dengan Kepala Seksi Pengembang Bidang Pasar Daerah Dinas Koperasi, UMKM, Perindustrian, dan Perdagangan bahwa pengembangan pasar ini dilakukan untuk meningkatkan daya saing pasar dan taraf hidup masyarakat. Bangunan pasar saat ini sudah tidak layak dan fasilitas juga tidak memenuhi. Jika kondisi pasar dibiarkan seperti ini tentunya lamakelamaan pasar tradisional akan punah (Dokumen Wawancara, Juni 2015).

Hal yang sama juga disampaikan oleh perwakilan dari IKWAPA. Berdasarkan hasil wawancara peneliti dengan sekretaris IKWAPA PPKS mengatakan bahwa mereka setuju dengan kegiatan pemerintah untuk pengembangan pasar mengingat warga pasar tradisional yang sudah sulit bersaing dengan pasar modern yang sekarang sudah menjamur. Konsumen saat ini banyak berbelanja ke pasar modern karena mereka sudah tidak mempermasalahkan harga, akan tetapi memerlukan kenyamanan saat berbelanja. Apalagi jika dihubungkan dengan pasar bebas saat ini, tentunya harus mempersiapkan diri agar mampu bersaing dengan para pedagang dari luar. Jika seluruh pedagang mampu untuk memahami pentingnya pengembangan pasar ini, tentu pengembangan pasar akan terlaksana tanpa adanya kendala (Dokumen Wawancara, Agustus 2015).

Terkait pengembangan pasar yang dikerjasamakan, berdasarkan hasil wawancara dengan Kepala Seksi Pengembangan, bahwa pemerintah menggandeng pihak ketiga dalam pengembangan pasar ini adalah karena setelah dibuat perhitungan, APBD Kabupaten Sumedang tidak cukup untuk melakukan pengembangan pasar. Pemerintah mengambil langkah cepat dengan menggandeng pihak ketiga agar pembangunan pasar dapat segera diolaksanakan (Dokumen Wawancara, Juni 2015). Sementara itu, berdasarkan hasil wawancara dengan sekretaris IKWAPAPPKS, bahwa awalnya 
warga pasar sebenarnya ingin pengembangan pasar dilaksanakan oleh pemerintah dengan pertimbangan dari sisi harga pasti lebih murah. Namun, akibat keterbatasan dana tersebut, akhirnya pedagang menerima kalau pengembangan diserahkan kepada pihak ketiga. Akan tetapi, tidak seluruh pedagang setuju dengan pengembangan pasar yang dikerjasamakan ini. Banyak terjadi pro dan kontra dari masyarakat (Dokumen Wawancara, Agustus 201).

Keterlambatan pemindahan pedagang ke TPS memperlihatkan bahwa tidak adanya tindakan nyata yang dilakukan oleh pemerintah, PT. BJA, dan IKWAPA untuk melakukan eksekusi pemindahan pedagang. Oleh karena itu, untuk mempercepat pembangunan pasar tentunya pemerintah, PT. BJA, dan IKWAPA PPKS harus melakukan tindakan korektif terhadap kendala pemindahan pedagang yang dihadapi. Untuk mendapatkan persetujuan dari pedagang tentu diperlukan keterbukaan informasi yang lebih agar seluruh warga pasar dapat memahami pentingnya pengembangan pasarini.

Komitmen juga sangat diperlukan dalam pelaksanaan kegiatan untuk mencapai tujuan yang diinginkan. Komitmen merupakan keterikatan untuk melakukan sesuatu. Dalam pelaksanaan suatu kegiatan, seluruh pihak yang terlibat harus memiliki komitmen dan tanggung jawab untuk mampu menyelesaikan pekerjaan. Tanpa adanya komitmen dari seluruh pihak, pasti akan ditemukan berbagai kendala terkait pengembangan pasar.

Dalam suatu kemitraan, seluruh pihak yang terlibat harus memiliki komitmen untuk mematuhi seluruh kesepakatan yang ada dan menyelesaikan kegiatan agar tercapainya tujuan. Komitmen dari pemerintah dan PT. BJA dijelaskan dalam surat perjanjian kerjasama Nomor 511/PKS.50-Huk/ 2013. Dalam surat tersebut dijelaskan kewajiban yang harus dilakukan oleh pemerintah dan PT. BJA selama kegiatan pengembangan pasar. Kewajiban tersebut dibuat berdasarkan hasil kesepakatan bersama dan tentu harus dilaksanakan. Selain itu, komitmen dari IKWAPA sebagai organisasi sosial juga sangat diperlukan. Sebagai organisasi yang menaungi seluruh aspirasi warga pasar, IKWAPA harus mampu menciptakan kelestarian pasar.

Berdasarkan hasil wawancara dengan Kepala Seksi Pengembangan bahwa untuk untuk menertibkan lingkungan pasar dan mengatasi penolakan dari pedagang, pemerintah sudah melakukan koordinasi dengan seluruh pihak yang terlibat untuk mencarikan solusi agar pengembangan pasar dapat segera dilaksanakan (Dokumen Wawancara, Juni 2015). Namun berbeda pandangan yang disampaikan oleh sekretaris IKWAPA bahwa pemerintah dianggap kurang tanggap dalam mengatasi kendala yang terjadi selama proses pengembangan pasar. Permasalahan yang ada di pasar dibiarkan berlarut-larut dan tidak ada tindak tegas dari pemerintah (Dokumen Wawancara, Agustus 2015).

Komitmen dalam setiap organisasi yang bermitra tentu diperlukan agar pelaksanaan pekerjaan dapat terlaksana dengan baik. Jika salah satu dari organisasi yang bermitra tidak memiliki komitmen untuk menyelesaikan pekerjaan tentu kemitraan tersebut akan mengalami kegagalan. Dalam hal, pemerintah sudah seharusnya melakukan tindakan tegas agar pengembangan pasar dapat terlaksana secepatnya. Jika tidak ada tindakan tegas dari pemerintah tentu akan merugikan banyak pihak, tidak hanya PT. BJA tetapi juga dapat merugikan pedagang pasar yang telah pindah ke tempat penampungan sementara.

\section{Pengawasan dalam Pelaksanaan Kemitraan.}

Pengawasan merupakan bagian yang tidak terpisahkan dari pelaksanaan kerjasama yang ditujukan untuk mengatur pelaksanaan pengembangan pasar oleh pihak-pihak yang terlibat. Pemerintah Daerah, pihak swasta (PT. BJA), IKWAPA beserta masyarakat harus mengawasi pelaksanaan pengembangan pasar untuk memastikan bahwa pelaksanaannya dapat berjalan dengan 
lancar dan tidak terjadi penyimpangan. Setiap tahapan dalam pengembangan pasar perlu diawasi agar kegiatan dapat terlaksana sesuai dengan waktu yang telah ditetapkan. Berdasarkan hasil wawancara dengan Kepala seksi pengembangan bahwa tahapan pengembangan pasar yaitu dengan membuat kebijakan untuk melakukan kegiatan pengembangan pasar mengingat kondisi pasar yang sudah tidak beraturan. Pemerintah kemudian melakukan sosialisasi kepada IKWAPA berserta masyarakat. Setelah adanya persetujuan dari masyarakat, pemerintah mencari mitra kerja dari pihak ketiga dan setelah terpilihnya PT. BJA, maka pihak swasta akan melakukan pembangunan(Dokumen Wawancara, Juni 2015).

Seperti yang disampaikan oleh Kepala Kantor Pemasaran PT. BJA dalam wawancara bahwa setelah bekerjasama dengan Pemerintah Daerah Kabupaten Sumedang, tahapan pengembangan pasar yang dilakukan oleh PT. BJA adalah mengurus izin-izin dan analisis dampak lingkungan, pembangunan TPS, pemindahan para pedagang ke TPS yang dibantu oleh pemerintah, penghancuran gedung lama, pembangunan pasar bernuansa semi modern, pemindahan pedagang dari TPS ke pasar pasca pembangunan, pengelolaan oleh pihak ketiga, dan penyerahan kembali kepada Pemerintah Daerah setelah waktu kerjasama berakhir (Dokumen Wawancara, Juni 2015). Hal yang sama juga disampaikan oleh sekretaris IKWAPA. Pengawasan perlu dilakukan dalam setiap tahapan pengembangan agar kendala-kendala yang dihadapi selama proses pengembangan dapat diketahui dan dicarikan solusinya (Dokumen Wawancara, Agustus 2015).

Wewenang pemerintah dalam pengawasan pengembangan pasar yaitu mengawasi pembangunan pasar yang dilakukan oleh pihak swasta dan mengawasi ketertiban lingkungan pasar agar terbebas dari PKL. Apabila terdapat penyimpangan, maka pemerintah berhak melakukan pengawasan yang dapat memberikan tindakan korektif dalam pelaksanaan pengembangan pasar sehingga dapat terlaksana dengan lancar.

Tidak hanya pemerintah yang memiliki hak untuk melakukan pengawasan. Untuk terciptanya keselarasan dalam kemitraan pengembangan pasar, PT. BJA dan IKWAPA PPKS juga melakukan pengawasan. Berdasarkan hasil wawancara dengan Kepala Kantor Pemasaran PT. BJA, bahwa PT. BJA juga melakukan pengawasan kegiatan pengembangan pasar. Pengawasan dilakukan oleh project manajer dengan melakukan pemantauan langsung ke pasar PPKS dan melihat kondisi yang ada. Jika terjadi kendala atau masalah, informasi-informasi yang didapat kemudian disampaikan kepada perusahaan dan dievaluasi bersama (Dokumen Wawancara, Juni 2015).

Selain itu, sekretaris IKWAPA dari hasil wawancara juga mengatakan bahwa IKWAPA juga melakukan pengawasan. IKWAPA membentuk panitia pengawalan pembangunan sebanyak 20 orang yang terdiri dari IKWAPA, pemilik kios, PKL, beserta masyarakat untuk mengawasi pengembangan pasar. Panitia ini melihat sejauh mana kegiatan yang telah dilakukan oleh pemerintah dan pengembang dalam melaksanakan kegiatan pengembangan pasar. Dengan dibangunnya TPS, panitia pengawalan pembangunan meninjau apakah pembangunan tersebut sesuai dengan kesepakatan. TPS yang dibangun diharapkan mampu bertahan selama masa pembangunan pasar dilaksanakan. Setiap terjadi masalah terkait pengembangan pasar, panitia melalui IKWAPA menyampaikan kepada pemerintah dan pihak swasta (Dokumen Wawancara, Agustus 2015). Peran serta IKWAPA dalam pengelolaan pasar ini selaras dengan AD dan ART IKWAPA PPKS, yang menyatakan bahwa IKWAPA berperan serta dalam membantu tugas pengelolaan pasar dalam rangka menciptakan kelestarian lingkungan pasar.

\section{Proses Negosiasi}

Terkait pengembangan pasar tersebut tentunya pemerintah melakukan negosiasi dan 
musyawarah kepada para pedagang. Berdasarkan hasil negosiasi dan musyawarah maka tertanggal 12 September 2012, didapatkan persetujuan dari warga pedagang pasar Sumedang Kota yang tertulis dalam surat pernyataan persetujuan Nomor 511.2/01/IKWAPA-Pasar/2012 dan Nomor 511.2/22/IKWAPA-Pasar/2012. Berdasarkan hasil persetujuan tersebut diharapkan pelaksanaan pembangunan pasar dapat dilakukan secepatnya. Akan tetapi berdasarkan observasi di pasar, hingga saat ini pembangunan pasar belum terlaksana karena berbagai faktor serta penolakan dari sebagian pedagang pasar. Berdasarkan hasil wawancara dengan sekretaris IKWAPA PPKS mengatakan bahwa negosiasi dan musyawarah bersama warga pasar terkait pengembangan pernah dilakukan, meskipun masih terdapat beberapa persoalan yang tidak sepenuhnya disepakati bersama(Dokumen Wawancara, Agustus 2015). Dalam Dokumen terbaru, tahun 2016 terkait Putusan Nomor 330/ PDT/2016/PT.BDG, dijelaskan bahwa Surat Pernyataan Persetujuan Warga Pedagang Pasar Sumedang Kota Nomor: 511.2/01/IKWAPA-PASAR/2012 Jo. Nomor : 511.2/22/ IKWAPAPASAR/ 2012 tertanggal 12 September 2012, yang menjadi dasar dibuatnya Surat Perjanjian Kerjasama antara Pemerintah Kabupaten Sumedang dengan PT. Bangun Jaya Allia Nomor :511/PKS.50-Huk/2013 Nomor : 1818/BJA/IX/2013 tentang Pembangunan Pasar Sumedang Kota Kabupaten Sumedang dan juga Kesepakatan Bersama antara Pemerintah Kabupaten Sumedang dengan PT. Bangunan Jaya Allia No. 511.2/NK.13-Huk/2013 Nomor : 19/I/BJA/2013 tentang : Revitalisasi Pembangunan Pasar Sumedang Kota, Kabupaten Sumedang, adalah tidak benar serta merupakan rekayasa.

Beberapa pedagang kemudian memunculkan berbagai alasan untuk menolak pengembangan pasar. Salah satu faktor pemicu penolakan pedagang adalah hak guna bangunan yang masih berlaku. Sesuai hasil wawancara dengan Kepala Seksi Pengembangan mengatakan bahwa terkait HGB yang masih berlaku, pemerintah, investor dan IKWAPA serta tokoh pedagang telah melakukan negosiasi terkait hal tersebut. Dari hasil musyawarah didapatkan kesepakatan bahwa pedagang yang masih memiliki hak guna bangunan akan mendapat kompensasi dalam bentuk uang muka terhadap kios baru pasca pengembangan pasar. Akan tetapi saat ini masih ada pedagang yang tidak mau pindah ke TPS dengan alasan Hak Guna Bangunan yang masih berlaku (Dokumen Wawancara, Juni 2015).

Penentuan Lay Out pasar juga melalui proses negosiasi yang panjang. Berdasarkan hasil wawancara dengan sekretaris IKWAPA bahwa penentuan gambar atau design pasar membutuhkan waktu lebih dari 4 bulan (Dokumen Wawancara, Agustus 2015.). Setiap kesepakatan yang diambil dinegosiasikan dan disosialisasikan kembali kepada warga pasar. Setelah melalui proses yang panjang maka didapat kesepakatan design pasar. Dalam pengembangan pasar ini pemerintah, PT. BJA, dan IKWAPA serta warga pasar telah melakukan negosiasi agar pelaksanaan pengembangan dapat terlaksana dengan adanya kesepakatan dari seluruh pihak yang terlibat. Akan tetapi proses negosiasi belum menemukan kesepakatan dengan pedagang. Masih terjadi penolakan dari beberapa pedagang terkait harga dan hak guna bangunan. Musyawarah antara Pemerintah, PT. Bangun Jaya Allia, IKWAPA beserta warga pasar perlu dilakukan agar dapat menemui kesepakatan dari seluruh pihak.

\section{Kesetaraan Peran}

Pemerintah Daerah Kabupaten sejauh ini melaksanakan tugas sesuai dengan kesepakatan yang telah dibuat. Berdasarkan hasil wawancara dengan Kepala Seksi Pengembangan bahwa setiap pihak dalam kemitraan telah memiliki peran masing-masing. Peran yang dilaksanakan ini merupakan kesepakatan bersama untuk terciptanya kesetaraan dalam pengembangan pasar. Dalam membuat kesepakatan, pemerintah, PT. BJA, IKWAPA beserta masyarakat berkumpul untuk menentukan 
kesepakatan bersama. Seluruh pihak yang terkait dalam kegiatan pengembangan pasar dijinkan untuk mengeluarkan pendapat. Peran yang dilaksanakan juga sesuai dengan peraturan perundangundangan dan surat perjanjian kerjasama (Dokumen Wawancara, Juni 2015).

Dalam kegiatan pengembangan pasar, pemerintah memiliki peran untuk menetapkan kebijakan dan strategi yang akan dilakukan. Pemerintah membuat kerangka acuan kerja tentang pengembangan pasar PPKS. Untuk melaksanakan pengembangan pasar, pemerintah menyelenggarakan proses pelelangan Badan Hukum Calon Mitra kerjasama dalam rangka rencana pengembangan pasar PPKS hingga terpilih PT. Bangun Jaya Allia sebagai mitra kerja. Dengan terpilihnya PT. BJA sebagai mitra kerjasama, pemerintah menyusun surat perjanjian kerjasama yang dirundingkan bersama PT. BJA, IKWAPA beserta tokoh-tokoh masyarakat. Kemudian pemerintah beserta pengembang dan IKWAPAmelakukan sosialisasi kepada masyarakat. Seperti yang dijelaskan dalam Peraturan Daerah Nomor 3 Tahun 2014 bahwa pemerintah daerah melalui dinas berkewajiban untuk menyebarluaskan data informasi pengelolaan pasar.

PT. BJA memiliki peran dalam pembangunan, penataan, pendanaan, dan pengelolaan pasar PPKS. Sejauh ini, PT. BJA telah melakukan penataan lokasi TPS dan membangun TPS disekitar Taman Endog (Patung Telor), jalan Tampomas untuk pemilik kios pasar. Selain itu, PT. Bangun Jaya Allia juga sudah melakukan pembangunan TPS di Jalan Ahmad Yani untuk para PKL. Terkait sumber pendanaan, berdasarkan hasil wawancara dengan Kepala Kantor Pemasaran PT. BJA bahwa sumber dana berasal dari aset tetap yang dimiliki oleh perusahaan (Dokumen Wawancara, Juni 2015). Untuk melakukan pembangunan pasar PPKS bernuansa modern, PT. BJA menggandeng pihak lain atau yang dikenal dengan subkontraktor. Akan tetapi, pembangunan pasar PPKS bernuansa modern belum dapat terealisasi mengingat pemindahan pedagang ke TPS yang belum dapat dilaksanakan.

Sementara IKWAPA telah membantu pemerintah menyosialisasikan kegiatan pengembangan pasar. Selain itu, pengurus IKWAPA juga telah melakukan pendekatan kepada warga pasar agar kegiatan tersebut disetujui oleh seluruh warga pasar. IKWAPA juga berperan untuk penampung aspirasi masyarakat terkait pengembangan pasar. Setiap hal yang diinginkan oleh warga pasar disampaikan oleh IKWAPA kepada pemerintah dan investor melalui rapat dan diskusi. Berdasarkan hasil wawancara dengan sekretaris IKWAPA bahwa dalam pengembangan pasar, IKWAPA beserta tokoh masyarakat diundang dalam setiap rapat atau musyawarah. IKWAPA diberikan kesempatan untuk menyampaikan keinginan dari masyarakat. Terkait gambar yang dibuat oleh pengembang pun, IKWAPA dan masyarakat juga dapat mengkritisi dan mengoreksi sesuai dengan keinginan warga (Dokumen Wawancara, Agustus 2015). Sebagaimana yang dijelaskan dalam Peraturan Daerah Nomor 3 Tahun 2014 bahwa peran serta masyarakat dapat dilakukan melalui:

a. Proses perencanaan dalam menyusun program beserta pengawasan evaluatif,

b. Pemberian usul, pertimbangan, dan saran kepada pemerintah,

c. Proses perumusan kebijakan pengelolaan pasar,

d. Pengawasan pengelolaan dan dapat melaporkan pada pihak berwenang bila terjadi kesalahan maupun pelanggaran pengelolaan.

\section{E. PENUTUP}

\section{Simpulan}

Public Social Private Partnership antara pemerintah daerah Kabupaten Sumedang, PT. BJA, dan IKWAPA PPKS merupakan salah satu kegiatan untuk mengembangkan pasar PPKS dengan membangun pasar PPKS menjadi pasar semi modern dan untuk meningkatkan pelayanan kepada para pedagang dan pembeli. Proses kemitraan ini sudah berlangsung selama kurang lebih 
tiga tahun namun pembangunan juga belum dapat dilaksanakan dengan baik dan menjadi dilema secara konseptual. Di satu sisi secara teoritik adanya kebutuhan untuk pelibatan multi-aktor dalam proses penyelenggaraan administrasi publik, akan tetapi di sisi lain pelibatan ini berdampak pada proses yang lebih sulit dalam mempertemukan kepentingan diantara aktor-aktor yang terlibat.

Selanjutnya, berdasarkan pembahasan sebelumnya dapat terlihat bahwa PSPP dalam pengembangan pasar PPKS di Kabupaten Sumedang belum sepenuhnya menerapkan prinsip-prinsip PSPP dengan baik. Dalam hal ini dapat dilihat diantaranya, prinsip transparansi belum dapat diterapkan dengan optimal. Sebagian informasi telah disampaikan diantara para aktor melalui berbagai pendekatan. Akan tetapi, dalam sosialisasi yang dilakukan untuk mendapatkan persetujuan dari pedagang belum mendapatkan hasil karena berbagai alasan dari pedagang untuk menolak kegiatan pengembangan pasar yang dilakukan pemerintah. Selain itu, tidak adanya koordinasi dalam pengawasan juga menyebabkan kendala dalam proses pembangunan pasar. Kemudian dalam menindaklanjuti hasil pengawasan yang dilakukan belum ada tindakan korektif baik itu dari pemerintah, PT. Bangun Jaya Allia dan IKWAPA PPKS untuk menyikapi kendala-kendala yang terjadi. Sementara dalam proses negosiasi sampai saat ini belum ada kesepakatan mutlak dari para pedagang untuk melakukan pengembangan pasar.

\section{Saran}

1. Selama proses pelaksanaan pengembangan pasar pemerintah, PT. BJA, dan IKWAPAPPKS harus mampu melakukan tindakan korektif dengan membuat tim pengawasan bersama sehingga proses pengawasan menjadi lebih terkoordinasi dengan baik.

2. PT. BJA harus tetap melibatkan para pedagang dalam negosiasi terkait segala bentuk keputusan yang menyangkut kehidupan anggota IKWAPA seperti terkait dengan variasi bentuk bangunan, harga jual kios, dll, agar tidak terjadi resistensi.

3. Komunikasi yang intensif yang setara serta dilandasi nilai-nilai kejujuran antara Pemda Kabupaten Sumedang, PT. BJA, dan IKWAPA beserta tokoh masyarakat adalah mutlak dilakukan agar kendala-kendala pengembangan pasar dapat dikelola dengan baik.

\section{DAFTAR PUSTAKA}

BPS Kabupaten Sumedang. (2015). Kabupaten Sumedang dalam Angka Tahun 2015. Dalam: https://sumedangkab.bps.go.id/index.php/publikasi/144. Diakses pada tanggal 15 Mei 2015.

Chhotray Vasudha dan Gerry Stoker. (2009). Governance Theory and Practice: A CrossDisciplinary Approach. Journal of Public Administration. Volume 87, Issue 4, pages 982983, December 2009

Creswell, John W. (2010). Research Design Pendekatan Kualitatif, Kuantitatif, dan Mixed. Yogyakarta. Pustaka Pelajar.

Dwiyanto, Agus. (2008). Mewujudkan Good Governance melalui Pelayanan Publik. Yogyakarta : Gadjah Mada University Press.

Fandel Gunter, Anke Giese, Brigitte Mohn. (2012). Measuring Synergy Effects of a Public Social Private Partnership (PSPP) Project. International Journal of Production Economics 140 (2012) 815-824.

Glasbergen, Pieter, Frank Biermann, and Arthur Mol, eds. (2007). Partnerships, Governance And Sus-tainable Development. Reflections on Theory and Practice. Cheltenham: Edward Elgar. 
Hughes, Owen E. (2012). Public Management and Administration: An Introduction. Basingstoke, United Kingdom: Palgrave Macmillan.

Kabupaten Sumedang. (2014). Peraturan Daerah Kabupaten Sumedang Nomor 3 Tahun 2014 tentang Pengelolaan dan Pemberdayaan Pasar Tradisional serta Penataan Pusat Perbelanjaan dan Toko Modern. Dalam: http://jdih.sumedangkab.go.id/Prodhuk/perda/2014/ Peraturan.Daerah_2014_3.pdf.Diakses pada tanggal 15 Mei 2015.

Kemenkumham. (2017). Peraturan Pemerintah Nomor 50 Tahun 2007 tentang Tata Cara Pelaksanaan Kerjasama Daerah. Dalam: http:/ditjenpp.kemenkumham.go.id/arsip/ln/2007/ pp50-2007.pdf. Diakses pada tanggal 15 Mei 2015.

Komisi Uni Eropa. (2004). Green Paper on Public-Private Partnerships and Community Law on Public Contracts and Concessions. Brusel: Commission of the European Communities.Leonhardt, Manfred, Brigitte Kukovetz dan Martina Haas. (2007). Public Social Private Partnership (PSPP). FH JOANNEUM Gesellschaft mbH, Graz. Dalam http://docplayer.org/26719364-Public-social-private-partnership-pspp-modell.html. Diakses pada tanggal 15 Mei 2015.

Miles, Matthew B dan Huberman, A Michael. (1994). Analisis Data Kualitatif. Jakarta. Universitas Indonesia Press.

Minogue, M., C. Polidano and D. Hulme, eds. (1998). Beyond the New Public Management: Changing Ideas and Practices in Government. Cheltenham: Edwin Elgar.

Moleong, Lexy J. (2007). Metodologi Penelitian Kualitatif. Bandung: Penerbit PT Remaja Rosdakarya.

Mullin, Rick. (1996). Managing The Outsourced Enterprise. Journal of Business Strategy, Vol. 17 Issue: 4, pp.28-36. Dalam: https://doi.org/10.1108/eb039792. Diakses pada tanggal 15 Mei 2015.

Osborne, Stephen P. (2010). The New Public Governance? : Emerging Perspectives on the Theory and Practice of Public Governance. London, United Kingdom: Routledge.

Porter, Michael E. and Mark R. Kramer. (2006). Strategy and Society. San Francisco: Harvard Business Review.

Setiawan, Tomi dan Sukma Egnas. (2012). Public Private Partnership as a Public Service Dilemma, dalam BISNIS \& BIROKRASI: Jurnal Ilmu Administrasi dan Organisasi, Vol 19, No 3 tahun 2012. Dalam http://journal.ui.ac.id/index.php/jbb/article/view/1855. Diakses pada tanggal 15 Mei 2015.

Vigoda-Gadot, Eran. (2002). Public Administration : An Interdisciplinary Critical Analysis. Haifa, Israel: CRC Press. 